\title{
Implementation of therapeutic hypothermia after cardiac arrest in intensive care units in Poland
}

\author{
Paweł Krawczyk, Gabriela Kołodziej, Bartłomiej Szpyra, Janusz Andres \\ Department of Anaesthesiology and Intensive Care, Jagiellonian University Medical College, Cracow, Poland
}

\begin{abstract}
Background: Therapeutic hypothermia (TH) is one of few interventions that improve survival after a cardiac arrest with good neurological outcome. Current guidelines for cardiopulmonary resuscitation recommend $\mathrm{TH}$ in comatose adult patients after return of spontaneous circulation (ROSC) regardless of cardiac arrest location and cardiac rhythm during the event.

Aim: To evaluate level of TH implementation in intensive care units (ICUs) in Poland and identify barriers to the implementation process.

Methods: A telephone survey was carried out to determine how many Polish ICUs were using TH in the management of comatose patients after a cardiac arrest. The survey was conducted from October to December 2010. The survey also included questions on the number of patients cooled, method of TH induction and maintenance, target temperature, duration of cooling, and cardiac arrest rhythm in patients treated with TH. We have also collected data on pre-hospital use of TH and potential barriers to implementation of $\mathrm{TH}$.

Results: We obtained information from 263 of 464 ICUs (56.8\%) in Poland. At the time of the survey, 57 ICUs (21.7\%) were using $\mathrm{TH}$ in comatose patients after ROSC. There was a significant increase in the number of ICUs using TH as compared with the 2005 survey. Most ICUs did not use any sophisticated equipment to induce and maintain TH. Ninety six percent of ICUs were using TH regardless of the cardiac arrest rhythm. In $65 \%$ of ICUs (37 units), target temperature was $32-34^{\circ} \mathrm{C}$ and $63 \%$ of ICUs (36 units) maintained TH for 12-24 hours. An increase in ICU experience in TH can be noted: $61 \%$ of ICUs (35 units) declared TH use in more than 10 patients during the last year. We found the following barriers to implementation of TH: lack of knowledge, lack of local protocols, lack of equipment, and economic issues.

Conclusions: The number of ICUs using TH in Poland increased threefold in the 5 year period of 2005-2010. However, the proportion of ICUs using TH is still low (21.7\%) compared to other European countries. Further efforts should be undertaken to reduce barriers to implementation of current resuscitation guidelines.
\end{abstract}

Key words: therapeutic hypothermia, implementation of resuscitation guidelines, barriers, post-cardiac arrest syndrome, post-resuscitation care

Kardiol Pol 2013; 71, 3: 270-274

\section{INTRODUCTION}

Therapeutic hypothermia $(\mathrm{TH})$, defined as controlled lowering of core body temperature to $32-34^{\circ} \mathrm{C}$ for $12-24$ hours, is one of few interventions that improve survival after cardiac arrest with good neurological outcome [1]. Improvement of outcomes in patients who suffered a cardiac arrest requires practical application of scientific knowledge on resuscitation, which is possible when adequate education and implementation strategies are used [2]. Current resuscitation guidelines recommend $\mathrm{TH}$ in patients after a cardiac arrest (regardless of its rhythm or location) who remain comatose (no reaction to verbal stimulation) after return of spontaneous circulation (ROSC) [1] but TH is still not considered a standard therapeutic procedure in many countries.

A survey on the use of $\mathrm{TH}$ in intensive care units (ICUs) in Poland conducted in 2005 showed that only $7.6 \%$ of these units used this therapeutic approach in patients after a cardiac arrest [3]. Recent data on the use of $\mathrm{TH}$ show a wide variation in the proportion of treated patients [4-6]. As no data are available on the current degree of guideline implementation

\section{Address for correspondence:}

Paweł Krawczyk, MD, PhD, Department of Anaesthesiology and Intensive Care, Jagiellonian University Medical College, ul. Kopernika 17, 31-501 Kraków, Poland, tel: +48 1242477 98, fax: +48 1242477 97, e-mail: krawczykpawel@wp.pl

Received: 19.05.2012 Accepted: 14.11.2012

Copyright (C) Polskie Towarzystwo Kardiologiczne 
regarding the use of $\mathrm{TH}$ in ICUs in Poland, we attempted to fill this gap in knowledge.

\section{METHODS}

From October to December 2010, a telephone survey was carried out in ICUs in Poland, using a database available to the national consultant in anaesthesiology and intensive care. The surveyed ICUs were run by specialists in anaesthesiology and intensive care and cared for both adult and paediatric patients. The purpose of the survey was to determine how many Polish ICUs were using TH in the management of COmatose patients after cardiac arrest and subsequent ROSC. The questionnaire included 9 items:

1. Do you use TH in your unit?

2. How many patients did you cool during the last year?

3. What methods do you use to induce and maintain $\mathrm{TH}$ ?

4. What is the target temperature?

5. What is the duration of $\mathrm{TH}$ ?

6. What rhythms of cardiac arrest do you consider when selecting patients for $\mathrm{TH}$ ?

7. Do you use pre-hospital $\mathrm{TH}$ ?

8. If you do not use $\mathrm{TH}$, do you plan to implement this treatment?

9. If you do not use $\mathrm{TH}$, what are the reasons for this?

The survey was supposed to be answered by chief ICU physicians, and if those were not available, by other physicians working in the ICU.

\section{RESULTS}

Using a database available to the national consultant in anaesthesiology and intensive care, we were able to contact by phone 363 of 464 ICUs in Poland. Data on the use of $\mathrm{TH}$ after cardiac arrest were obtained from 263 ICUs (56.8\% of all units). Reasons for lacking data from the remaining ICUs included inability to contact a given unit by phone (despite repeated attempts), inability to obtain information due to lack of appropriately informed or authorised healthcare personnel, lack of consent, and lack of willingness to participate in a telephone survey. If an attempt to contact a unit and obtain information on the use of $\mathrm{TH}$ was successful, all required data were collected in all cases. The use of $\mathrm{TH}$ was reported by 57 ICUs (21.7\%) of the surveyed units. Figure 1 shows an administrative map of Poland with voivodeships and numbers of ICUs using $\mathrm{TH}$ in each voivodeship.

Comparison of the current survey results with those of a 2005 survey [3] showed a threefold increase in the proportion of ICUs using TH (7.6\% vs. $21.7 \%)$. Other results of the survey are shown in Table 1.

Most units reporting the use of $\mathrm{TH}(84 \%)$ cooled more than 5 patients during the last year. External (noninvasive) methods were primarily used, most commonly (60\%) cold packing with ice packs or cooled gels. Five ICUs used dedi-

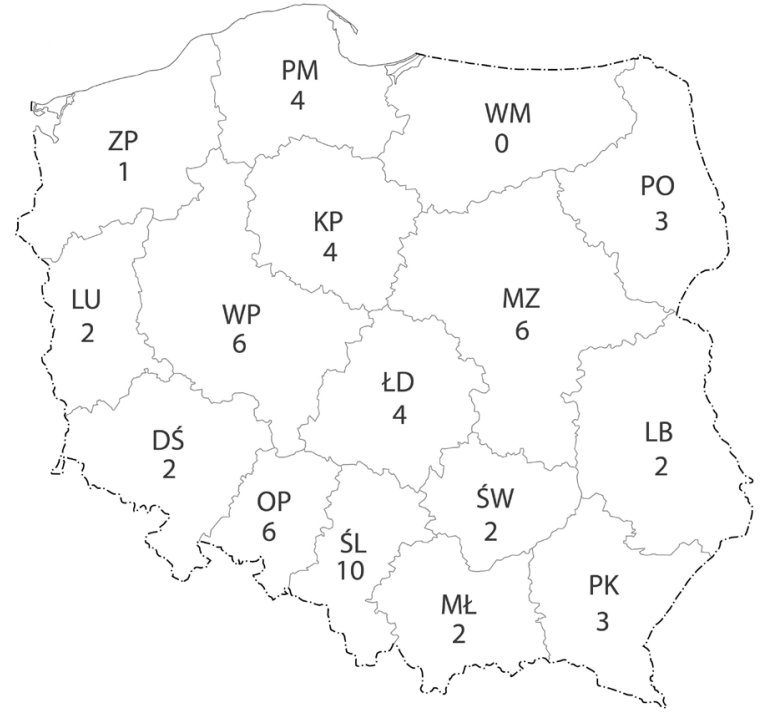

Figure 1. Location and number of intensive care units using therapeutic hypothermia after cardiac arrest. Voivodeships: DŚ - Lower Silesian (dolnośląskie); KP — Kuyavian-Pomeranian (kujawsko-pomorskie); LB — Lublin (lubelskie); LU Lubusz (lubuskie); ŁD — Łódź (łódzkie); MŁ — Lesser Poland (małopolskie); MZ — Masovian (mazowieckie); OP — Opole (opolskie); PK — Subcarpathian (podkarpackie); PM — Pomeranian (pomorskie); PO — Podlaskie (podlaskie); ŚL — Silesian (śląskie); ŚW — Świętokrzyskie (świętokrzyskie); WM — Warmian-Masurian (warmińsko-mazurskie); WP — Greater Poland (wielkopolskie); ZP — West Pomeranian (zachodniopomorskie)

cated equipment for noninvasive $\mathrm{TH}$ including cooling gel mats or body wraps and cool caps. Other external cooling methods (13 units - 18.5\%) included cold head packs and cooling with fans to induce air flow around the patient with additional skin moisturising to enhance cooling by water evaporation. Intravenous infusions of cold fluids were used in only $8.5 \%$ of cases, and other internal cooling methods including stomach or bladder washing with cold fluids were used in $6 \%$ of patients. Target temperature was $32-34^{\circ} \mathrm{C}$ in $65 \%$ of ICUs, $63 \%$ units used $\mathrm{TH}$ for $12-24$ hours, and $26 \%$ units used TH for more than 24 hours. Nearly all ICUs used $\mathrm{TH}$ regardless of the cardiac arrest rhythm. Prehospital TH was used in $4 \%$ of units.

Seventy of 206 ICUs not using TH planned to implement this treatment method in patients after cardiac arrest. The most commonly reported reasons for not using $\mathrm{TH}$ included lack of knowledge, experience, local protocols, specialised equipment, or financial limitations, e.g. lack of reimbursement of expenses related to the use of this therapeutic approach.

\section{DISCUSSION}

Our findings indicate nearly threefold increase in the use of $\mathrm{TH}$ by ICUs in Poland during 5 years. However, still only $21.7 \%$ 
Table 1. Results of the survey on the use of therapeutic hypotermia in intensive care units in Poland

\begin{tabular}{|c|c|}
\hline $\begin{array}{l}\text { Number of patients treated with TH } \\
\text { during the last year }\end{array}$ & Proportion \\
\hline $1-5$ & $16 \%(9 / 57)$ \\
\hline $6-10$ & $23 \%(13 / 57)$ \\
\hline $11-20$ & $17 \%(10 / 57)$ \\
\hline$>20$ & $44 \%(25 / 57)$ \\
\hline \multicolumn{2}{|l|}{ Methods used to induce/maintain $\mathrm{TH}^{*}$} \\
\hline \multicolumn{2}{|l|}{ Internal } \\
\hline Cold intravenous fluids & $8.5 \%(6 / 70)$ \\
\hline Dedicated TH devices & $0 \%(0 / 70)$ \\
\hline Other (see text) & $6 \%(4 / 70)$ \\
\hline \multicolumn{2}{|l|}{ External } \\
\hline Cold packing (ice packs, cooled gels) & $60 \%(42 / 70)$ \\
\hline Dedicated TH devices & $7 \%(5 / 70)$ \\
\hline Other (see text) & $18.5 \%(13 / 70)$ \\
\hline \multicolumn{2}{|l|}{ Target temperature } \\
\hline $32-34^{\circ} \mathrm{C}$ & $65 \%(37 / 57)$ \\
\hline Other & $35 \%(20 / 57)$ \\
\hline \multicolumn{2}{|l|}{ Duration of TH } \\
\hline $12-24 \mathrm{~h}$ & $63 \%(36 / 57)$ \\
\hline$>24 \mathrm{~h}$ & $26 \%(15 / 57)$ \\
\hline$<12 \mathrm{~h}$ & $11 \%(6 / 57)$ \\
\hline \multicolumn{2}{|c|}{ Cardiac arrest rhythms in patients treated with TH } \\
\hline Shockable rhythms only (VF/NT) & $2 \%(1 / 57)$ \\
\hline $\begin{array}{l}\text { Non-shockable rhythms only } \\
\text { (PEA/asystole) }\end{array}$ & $2 \%(1 / 57)$ \\
\hline All cardiac arrest rhythms & $96 \%(55 / 57)$ \\
\hline \multicolumn{2}{|l|}{ Prehospital TH use } \\
\hline Yes & $4 \%(2 / 57)$ \\
\hline No & $96 \%(55 / 57)$ \\
\hline \multicolumn{2}{|l|}{$\begin{array}{l}\text { Planned implementation of TH } \\
\text { (by units currently not using TH) }\end{array}$} \\
\hline Yes & $34 \%(70 / 206)$ \\
\hline No & $66 \%(136 / 206)$ \\
\hline \multicolumn{2}{|l|}{ Reasons for not using TH } \\
\hline Lack of knowledge, experience, protocols & $22 \%(45 / 206)$ \\
\hline Lack of equipment, funding & $22 \%(45 / 206)$ \\
\hline Both & $56 \%(116 / 206)$ \\
\hline
\end{tabular}

* Units could report more than 1 method; $\mathrm{TH}$ - therapeutic hypothermia; PEA — pulseless electrical activity; VF — ventricular fibrillation; VT — ventricular tachycardia

of surveyed ICUs use TH. Nearly all units using TH cooled patients regardless of cardiac arrest rhythms. In $65 \%$ of ICUs (37 unit), target temperature was $32-34^{\circ} \mathrm{C}$, and $63 \%$ of ICUs
(36 units) used TH for 12-24 hours. Survey results show that $26 \%$ of ICUs (15 units) use TH for more than 24 hours. Currently available data do not suggest any benefits of extended duration of TH in adult patients after cardiac arrest and subsequent ROSC, although the optimal duration of $\mathrm{TH}$ has not been clearly defined [7].

Experience of Polish centres with this treatment approach is increasing. More than 10 patients were cooled during the last year in $61 \%$ of ICUs (35 units) using TH. A vast majority of units do not use any dedicated $\mathrm{TH}$ equipment. A major limitation reported by the surveyed centres is the financial aspect, i.e. higher costs of $\mathrm{TH}$ using dedicated equipment. Currently available literature data do not indicate better outcome of TH using dedicated equipment but the use of the latter is associated with significant advantages in terms of improved temperature stability and decreased workload of the healthcare personnel $[1,8]$.

The most commonly used approach to $\mathrm{TH}$ in ICUs in Poland involved cold packing with ice packs or cooled gels, and the use of fans to induce air flow around the patient. Cold crystalloid infusion was used to induce TH in only $8.5 \%$ of cases. The 2010 resuscitation guidelines recommend $\mathrm{TH}$ induction with intravenous infusion of $30 \mathrm{~mL} / \mathrm{kg}$ of crystalloids cooled to $4^{\circ} \mathrm{C}$. This results in a rapid lowering of core body temperature by $1.6^{\circ} \mathrm{C}[1,9]$ and helps achieve the target temperature faster without any significant adverse effects.

Results of our survey indicate that $\mathrm{TH}$ is rarely initiated in the prehospital phase. Report on the use of TH in humans do not suggest any significant benefits of early implementation of $\mathrm{TH}$, and a time window of 4 hours has been proposed. Animal models showed improved neurological outcome and increased rate of ROSC with earlier implementation of $\mathrm{TH}$, even during cardiac arrest $[10,11]$.

Data collected from those ICUs that did not use $\mathrm{TH}$ indicate that $34 \%$ of them (70 ICUs) plan to implement this therapeutic approach. Main reported barriers included lack of treatment protocols, knowledge and experience with this method. Respondents also reported barriers related to limited access to dedicated equipment, and problems with reimbursement of expenses related to the use of $\mathrm{TH}$. This is a major problem impending implementation of $\mathrm{TH}$ in patients after cardiac arrest, although inexpensive noninvasive protocols have been reported in the literature that allow effective institution of TH without the use of sophisticated equipment [12].

Numerous aspects of barriers to the implementation of $\mathrm{TH}$ have been discussed in the literature. Most commonly identified barriers include lack of awareness or knowledge of guidelines and clear evidence of benefits presented in these documents; lack of self-confidence and belief in the positive effects of intervention; therapeutic inertia; lack of detailed treatment protocols; and barriers related to interdisciplinary care of patients after cardiac arrest (emergency medicine, intensive care, nursing) [13]. 
Literature data indicate that intensive education and implementation programs may result in a significant improvement regarding the use of $\mathrm{TH}$. For example, wide implementation of $\mathrm{TH}$ in the United Kingdom (an increase in the rate of TH use from $28 \%$ to $85.6 \%$ of patients after cardiac arrest) took place within only about 5 years [4]. Improved implementation of TH may also be related with prehospital use of this treatment approach: in some areas of the Czech Republic, up to $70 \%$ of centres have been reported to initiate TH during prehospital phase [14].

The Czech experience also suggests that implementation of $\mathrm{TH}$ benefited from issuing a national consensus statement on $\mathrm{TH}$, dissemination of ready-to-use $\mathrm{TH}$ protocols, and undertaking research projects related to $\mathrm{TH}$. The rate of $\mathrm{TH}$ use was higher in units admitting more that 10 patients after a cardiac arrest annually [6, 14].

The major limitation of our study was inability to obtain information from all ICUs in Poland. We did not analyse TH use separately in paediatric patients. Importantly, patients after a cardiac arrest are also managed in intensive coronary care units and cardiac catheterisation laboratories, but data from these centres were not collected in our study.

\section{CONCLUSIONS}

Therapeutic hypothermia in comatose patients after cardiac arrest has not become a standard treatment used in ICUs in Poland. Identified barriers to guideline implementation include lack of knowledge, experience, local protocols, and national guidelines, as well as lack of reimbursement of costs of this therapy. Efforts to improve this situation should be targeted at comprehensive and interdisciplinary initiatives approved by recognised scientific societies and other advisory bodies.

\section{Conflict of interest: none declared}

\section{References}

1. Deakin CD, Nolan JP, Soar J et al. European Resuscitation Council Guidelines for Resuscitation 2010 Section 4. Adult advanced life support. Resuscitation, 2010; 81: 1305-1352.
2. Soar J, Mancini ME, Bhanji F et al. Part 12: Education, implementation, and teams: 2010 International Consensus on Cardiopulmonary Resuscitation and Emergency Cardiovascular Care Science with Treatment Recommendations. Resuscitation, 2010; 81 (suppl. 1): e288-e330.

3. Krawczyk P, Fraczek B, Drab E. Use of therapeutic hypothermia in Polish intensive care units. Resuscitation, 2008; 79: 339.

4. Binks AC, Murphy R E, Prout RE et al. Therapeutic hypothermia after cardiac arrest - implementation in UK intensive care units. Anaesthesia, 2010; 65: 260-265.

5. Oksanen T, Pettilä V, Hynynen M, Varpula T and Intensive Consortium study group. Therapeutic hypothermia after cardiac arrest: implementation and outcome in Finnish intensive care units. Acta Anaesthesiol Scand, 2007; 51: 866-871.

6. Skulec R, Truhlar A, Knor J et al. Broad implementation of therapeutic hypothermia after cardiac arrest-Mission possible. Resuscitation, 2010; 81: 779-780.

7. Walters JH, Morley PT, Nolan JP. The role of hypothermia in post-cardiac arrest patients with return of spontaneous circulation: a systematic review. Resuscitation, 2011; 82: 508-516.

8. Knapik P, Rychlik W, Siedy J et al. Comparison of intravascular and conventional hypothermia after cardiac arrest. Kardiol Pol, 2011; 69: 1157-1163.

9. Bernard S, Buist M, Monteiro O, Smith K. Induced hypothermia using large volume, ice-cold intravenous fluid in comatose survivors of out-of-hospital cardiac arrest: a preliminary report. Resuscitation, 2003; 56: 9-13.

10. Riter HG, Brooks LA, Pretorius AM, Ackermann LW, Kerber RE. Intra-arrest hypothermia: both cold liquid ventilation with perfluorocarbons and cold intravenous saline rapidly achieve hypothermia, but only cold liquid ventilation improves resumption of spontaneous circulation. Resuscitation, 2009; 80: 561-566.

11. Staffey KS, Dendi R, Brooks LA et al. Liquid ventilation with perfluorocarbons facilitates resumption of spontaneous circulation in a swine cardiac arrest model. Resuscitation, 2008; 78: 77-84.

12. Kory P, Weiner J, Mathew JP et al. A rapid, safe, and low-cost technique for the induction of mild therapeutic hypothermia in post-cardiac arrest patients. Resuscitation, 2011; 82: 15-20.

13. Brooks SC, Morrison LJ. Implementation of therapeutic hypothermia guidelines for post-cardiac arrest syndrome at a glacial pace: seeking guidance from the knowledge translation literature. Resuscitation, 2008; 77: 286-292.

14. Skulec R, Truhlár A, Seblová J et al. Implementation of pre-hospital therapeutic hypothermia in post-cardiac arrest patients in the Czech Republic. Resuscitation, 2012; 83: e21-e22. 


\title{
Implementacja hipotermii terapeutycznej po zatrzymaniu krążenia na oddziałach anestezjologii i intensywnej terapii w Polsce
}

\author{
Paweł Krawczyk, Gabriela Kołodziej, Bartłomiej Szpyra, Janusz Andres \\ Katedra Anestezjologii i Intensywnej Terapii, Uniwersytet Jagielloński Collegium Medicum, Kraków
}

\section{Streszczenie}

Wstęp: Hipotermia terapeutyczna (TH) jest jedną z niewielu interwencji o udowodnionym wpływie na poprawę przeżycia z dobrym wynikiem neurologicznym leczenia u pacjentów po zatrzymaniu krążenia. Aktualne wytyczne resuscytacji krążeniowo-oddechowej zalecają kontrolę temperatury i zastosowanie TH u dorosłych pacjentów pozostających w stanie śpiączki po zatrzymaniu krążenia, niezależnie od jego mechanizmu i lokalizacji.

Cel: Celem pracy była ocena stanu implementacji TH po zatrzymaniu krążenia na polskich oddziałach anestezjologii i intensywnej terapii (OAIT) i próba identyfikacji ograniczeń w implementacji wytycznych resuscytacji.

Metody: W okresie od października do grudnia 2010 r. przeprowadzono telefoniczną ankietę mającą na celu ocenę, ile OAIT w Polsce stosuje TH jako terapię u pacjentów pozostających w stanie śpiączki po zatrzymaniu krążenia. Pozostałe zagadnienia ujęte w ankiecie dotyczyły: liczby schłodzonych pacjentów, stosowanej metody schładzania, temperatury docelowej, czasu stosowania TH i mechanizmu zatrzymania krążenia. Zbierano również dane dotyczące przedszpitalnego zastosowania TH i identyfikacji potencjalnych barier dla implementacji TH.

Wyniki: Informację zwrotną uzyskano z 263 OAIT spośród 464 polskich OAIT (56,8\%). Spośród nich 57 (21,7\%) stosuje TH jako postępowanie wdrożone u pacjentów z przywróconym krążeniem. Większość ośrodków nie używa specjalistycznego sprzętu do indukcji czy podtrzymania hipotermii; 96\% ośrodków (55 OAIT) stosujących TH robi to niezależnie od mechanizmu zatrzymania krążenia; 65\% ośrodków (37 OAIT) stosuje docelowo temperaturę 32-34 ${ }^{\circ} \mathrm{C}$, a $63 \%$ (36 OAIT) utrzymuje hipotermię przez 12-24 godzin. Rośnie doświadczenie ośrodków: 61\% z nich (35 OAIT) deklaruje zastosowanie TH w ciągu ostatniego roku u ponad 10 pacjentów. Stwierdzono istotne bariery w implementacji TH — brak rozpowszechnienia wiedzy dotyczącej wytycznych, brak lokalnych protokołów, brak sprzętu do prowadzenia TH i problemy z finansowaniem tego rodzaju terapii. Wnioski: W latach 2005-2010 3-krotnie wzrosła liczba OAIT stosujących TH (7,6\% vs. 21,7\%), ale jest to wciąż niski odsetek w porównaniu z innymi krajami europejskimi. Dalsze prace powinny być ukierunkowane na zwalczanie barier w implementacji wytycznych resuscytacji.

Słowa kluczowe: hipotermia terapeutyczna, bariery, implementacja, resuscytacja, opieka poresuscytacyjna, syndrom poresuscytacyjny

Kardiol Pol 2013; 71, 3: 270-274

\section{Adres do korespondencji:}

dr n. med. Paweł Krawczyk, Katedra Anestezjologii i Intensywnej Terapii, Uniwersytet Jagielloński, Collegium Medicum, ul. Kopernika 17, 31 -501 Kraków,

tel: +48 1242477 98, faks: +48 1242477 97, e-mail: krawczykpawel@wp.pl

Praca wpłynęła: 19.05.2012 r.

Zaakceptowana do druku: 14.11.2012 r. 